\title{
Pluralism, Vitality, and Transformability: A Case Study of Jining Religions in the Late Imperial and Republican Periods
}

\author{
Jinghao Sun $^{1}$ \\ ${ }^{1}$ History Department, East China Normal University, Shanghai, China \\ Correspondence: Jinghao Sun, History Department, East China Normal University, Shanghai 200241, China. Tel: \\ 86-150-2100-6037. E-mail: jinghaosun@yahoo.com
}

Received: March 12, 2012 Accepted: June 4, 2012 Online Published: July 1, 2012

doi:10.5539/ach.v4n2p16 URL: http://dx.doi.org/10.5539/ach.v4n2p16

The final completion and publication of this article was supported by the New Century Program to Promote Excellent University Talents (no.: NECJ-10-0355).

\begin{abstract}
This article depicts the dynamic demonstrations of religions in late imperial and republican Jining. It argues with evidences that the open, tolerant and advanced urban circumstances and atmosphere nurtured the diversity and prosperity of formal religions in Jining in much of the Ming and Qing periods. It also argues that the same air and ethos enabled Jining to less difficultly adapt to the West-led modern epoch, with a notable result of welcoming Christianity, quite exceptional in hinterland China.
\end{abstract}

Keywords: Jining, religions, urban, Grand Canal, hinterland, Christianity

\section{Introduction: A Special Case beyond Conventional Scholarly Images}

It seems a commonplace that intellectual and religious beliefs and practices in imperial Chinese inlands were conservative, which encouraged orthodoxy ideology or otherwise turned to heretic sectarianism. It is also commonplace that in the post-Opium War modern era, hinterland China, while being sluggishly appropriated into Westernized modernization, persistently resisted the penetration of Western values and institutes including Christianity. In particular in western Shandong, an eastern province in north China, a number of severe missionary conflict cases in the last quarter of the nineteenth century and the subsequent Boxer Rebellion in 1900 marked it as a hectic hotbed of xenophobia or anti-foreignism. (Note 1)

Situated in southwestern Shandong, however, Jining city appeared pretty unique in nourishing multiple religions and cults yet snubbing heathenism in the late imperial period (Note 2), and then favoring Western civilizations including Christianity from the late nineteenth century to the mid-twentieth century. What and how did this uniqueness manifest, what elements were accounted for this? In this article, I will first survey this distinctive religious existence prior to the mid-nineteen century when China began to be amalgamated into the stream of modern world history dominated by Western material and cultural powers. With an understanding of its post, I will then examine how Christianity spread in the greater Jining area, and why Jining was so special.

\section{Religious Diversity and Prosperity in a Tolerant Grand Canal Port in the Late Imperial Period}

Western Shandong was by and large a traditional agricultural area with lower commercialization and urbanization prior to the mid-Ming in the imperial period. However, during much of the Ming and Qing periods till the mid-nineteenth century, Jining remained as a metropolis along the Grand Canal, the lifeblood for the empires. Just seating in the middle-point of the Canal, there were enormous and intensive convergence and exchange of goods, institutes and human resources, which remodeled the economic orientation and identity of the locality. (Note 3) In the wake of the booming market economy channeled by the Grand Canal in the mid-Ming, a distinctive cultural flowering began to occur.

Geographically adjacent to Qufu, Confucius's hometown, and Zouxian, Mencius's hometown, Jining had a lasting leading tradition of Confucian studies. This tradition was mirrored by the large number of students who 
were successful in passing the imperial civil service examination. (Note 4) As a result, Jining had a large and powerful local gentry-society. (Note 5) During the city's efflorescence, both elite culture and popular culture flourished. Nonetheless, different from most northern elites, Jining gentry's inclination to exert influence on mass culture by invoking Jining as "the sages' land" was largely ineffective in blunting the impact of commerce and communication on urban customs and urbanites' ways of thinking. This local cultural ethos robustly furthered vibrant popular culture and lifestyle in the everyday life in Jining city and its vicinities. (Note 6) In this liberal air, Many Buddhist, Daoist and Islamic cults and popular deities were widely worshiped by the populace, and the elite as well. This flourishing situation was quite extraordinary in the North.

In late imperial China, Buddhism was often juxtaposed with Confucianism by gentry elites. Jining's wealth provided financial resources for Buddhist undertakings, and a highly tolerant spirit in the local intellectual circles cherished its influence. In Jining there were several well-known Buddhist monasteries, which attracted pilgrimages both from neighboring countryside and afar. In addition, a variety of beliefs in Jining corresponded to diverse cultural, territorial and ethnic backgrounds. For example, Islam rapidly spread along the canal. To serve the large Muslim community, several ornate Islamic mosques were scattered throughout both the city and the suburbs. (Note 7) This colorful cultural montage conformed to the complex mixture of mobile population along the Canal.

In sum, the existence of the pantheon of deities and supernatural worship in urban Jining had to do with its open and fluid social environment, though Chinese local society used to be a polytheistic world. At the same time, despite its religious multiplicity, heterodox sects such as the White Lotus, Red Spear, Boxers - which were all widely active in western Shandong hinterland especially along the border between Shandong and Henan - were weak or nearly none in urban Jining and its immediate suburbs. (Note 8) Heretical teachings and doctrines only elicited interest in Jining's neighboring rural peripheries. Overall, Jining stayed away from seditious religious activities in western Shandong. It seems that a higher-degree and stable urban society and culture on one hand accommodated plural voices and lifestyles, yet on the other hand efficiently restrained the budding growth of any insurgent teachings and practice in the daily life of Jining urbanites, thus minimizing potential menace.

\section{The Influx of Gospels in a Unique Hinterland City}

Jining's emergence from obscurity was because of the rise of Grand Canal transportation in the early Ming. It was the Grand Canal that brought about vigor and mobility to Jining, as well as many other inland places along its route, and sustained its economic and cultural prosperity and dynamics in the late imperial period. However, from the mid-nineteenth century onward unprecedented natural and social domestic and international occurrences sharply eroded the foundation of Jining's success, along with the whole greater northern canal region. With the state no longer counting on the Grand Canal as the national artery, Jining and other northern canal cities were threatened with the ruin of their entire human and environmental equilibriums. The state otherwise shifted its strategic gravity to new enterprises in the coastal areas. (Note 9) Consequently, while the eastern coasts became new economic and cultural centers in light of the permeation of Western civilizations including capitalism or imperialism, the once-glorious northern canal areas were downgraded to hinterlands and even backwaters.

However, the undertakings by Jining's powerful and open-minded elites tried to hold back their locality's decline in the last quarter of the Qing. Knowing the significance of transportation from past experience, Jining elites promoted the construction of railways and modern road systems, which helped its initial modern economic transformation after the Western pattern of industrialization. (Note 10)Next, in the Republic epoch prior to the overall Japanese occupation in late 1937, regardless of endless political and social chaos, the changing elites and growing new urbanities engaged in building modern urban identity in their locality in devastated, impoverished rural western Shandong. (Note 11) As such, the continuity and rejuvenation of Jining's liberal and open environments and ethos enabled it adaptable to new values and fashions, as well as human, financial and institution resources from without. The significance of foreigners increased from the late nineteenth century and steadily influenced the everyday life of Jining people. Among them, Western missionaries and their churches, hospitals, schools, libraries and communities took the lead.

Based on privileges stemming from unequal treaties and powerful financial resources, Christianity became widespread in Shandong, though often caught in the fragile tensions which developed within antagonistic gentry, officials and masses, leading to numerous radical clashes in Shandong in the late Qing and early Republican periods. While western Shandong was constantly mired in endless legal and violent conflicts, in Jining there were no severe clashes with missionaries. (Note 12) Most of violence was related to unofficial local armed societies or secrete societies that could organize effective actions. The famous Juye missionary tragedy occurred 
in 1897 near Jining. (Note 13)

The Catholic Divine Word Society was the first to arrive in Jining. In 1882, the Austrian priest Joseph Freinademetz (1852-1908) and the German priest Johann Baptist von Anzer (1851-1903) came to Jining to open the southern Shandong diocese (for Yanzhou, Yizhou, Caozhou and Jining prefectures) for the Society of Divine Word. (Note 14) Their arrival first introduced a Western religion into the local community. They wore Chinese clothing, spoke the dialect, and performed Chinese rites and local customs. Joseph Freinademetz even braided a Manchu queue. Initially, their missionary achievements were mainly in rural areas in Yanzhou, Jining and Caozhou territories. Until 1891, they had only established a chapel in Jining city with a dozen converts. But, with the increase of the German presence in Shandong, they gradually expanded their influence. In 1894, a magnificent church was constructed in the southeastern ward of the town by Joseph Freinademetz. This Greek architectural-style building was 720 square meters large, and its peak was 165 meters high, and it could house a congregation of 1,200 persons. In 1898 the resolution of the 1897 Juye incident was the legitimization of Germany's priority of presence in Shandong. The Chinese indemnities provided Joseph Freinademetz and Johann Baptist von Anzer plenty of funds to repair and construct churches. After the suppression of the Boxer Rebellion in 1900, Germany steadily expanded its hegemony in Shandong, which also ushered in an era of unprecedented growth in evangelization. (Note 15)

The German Divine Word Society took Jining as the center of its mission in southwestern Shandong. In Daizhuang village, 4 kilometers north of Jining, they occupied the acclaimed Jin Yuan historical garden in 1887, and established an enormous church compound with comprehensive facilities on land of $200 \mathrm{mu}$. It owned around 3,000 mu farmland in rural Jining County in the 1910s. During the Japanese occupation, people often sought refuge from the enemy in Daizhuang village which once shielded about 200,000. (Note 16) According to a statistical investigation in the early $1950 \mathrm{~s}$, Catholic churches established one middle school, two elementary schools, one girls' school, one normal school, and four hospitals in Jining. (Note 17)

Protestant missions arrived in tandem with Catholic missions. In 1887, an American Presbyterian pastor Gilbert Reid (1857-1927) reached Jining. (Note 18) Gradually Jining was developed into a major headquarters for the Presbyterian mission, which quickly expanded its influence, mostly in the urban and suburban areas. The famous American missionary Calvin Wilson Mateer (1836-1908) once worked in Jining. Presbyterian missionaries in Jining concentrated on establishing hospitals and schools. The mission had subsidiary schools from kindergarten to college, and several hospitals. These establishments emphasized training Chinese personnel.

Besides religious and institutional works, the Presbyterians showed their enthusiasm in reshaping social customs by proposing or organizing the following broad social curriculums in both their schools and in public, and all these programs and activities promoted interest in new life styles and colored the cityscape. They were: 1) Sport matches. Periodic sports meetings were held seasonally. 2) Modern drama performances. 3) Women's liberation such as abolishing foot-binding, stylish haircuts, and equal right to go to school. 4) Free marriage, gender equality. 5) Anti-illiteracy campaigns. 6) Quiz games. 7) Introduction of Western music and instruments. (Note 19)American Baptist missionaries arrived in Jining a little later. Their first missionary was a Chinese named Li Shouting who formally formed the first Baptist society in Jining in 1918. With such as foothold, the Chinese and American Baptist ministers worked effectively together so that since the mid-1930s Jining had become a Baptist mission center for the surrounding area. (Note 20)

Both Catholic and Protestant missionaries combined missionary and social welfare jobs and therefore expanded their influence. At the beginning, they provided free medical treatment and free immunization. They grew fast in the early Republican period. In all of Shandong in 1914, there were about 454 Protestant priests and 35 missionary doctors. (Note 21) According to a Japanese statistics in 1938, there were 107 Catholic and Protestant ministers in Jining County who mostly lived in the city. (Note 22) A report from the Communist police dated on August 11, 1948 shows there were then three Catholic churches with 918 converts, and five Protestant churches with 633 converts. Among the 3,641 adherents who were attached to a dozen religious institutions and superstitious practice throughout the whole county, the number of Christian believers in total surpassed the number of formal converts of any single domestic religion. (Note 23) In contrast, Buddhism and Daoism began to decline. The 1927 county gazetteer compilers admit the fading of Buddhism, most of whose temples had fallen down. (Note 24)

There were scattered records about other Western professionals' activities in commerce, industry and other arenas, but no extant statistics have been found. (Note 25) In short, foreign missionaries or professionals may have favored Jining because of its regional importance and its relatively tolerant and stable urban condition. The escalating foreign presence in Jining meant the city was drawn within the influence of globalization. Through 
this process Western religions made serious inroads into life in this interior city. These changes in the urban space of Jining provided people with more choices in careers and values.

\section{Conclusion: Cultural and Religious Dynamic in a Liberal Interior}

Located in an intermediate position of the north-south nationwide transportation and communication via the Grand Canal, multiple socio-cultural characters took root in late imperial Jining in spite of the mainstream of Confucianism. This was why formal religions, especially Buddhism, prospered, and at the same time due to its advanced urbanity, vulgar, secret, or insubordinate sectarianism and superstitions did not gain toehold in Jining.

From the late nineteenth century, Jining faced challenges beyond yet a dynastic cycle: not only the decline of canal transportation but also unprecedented changes in the national economic network and mode of production brought about by the alien forces of modernity, capitalism, and Christianity. New changes dramatically occurred in religious and cultural realms in Jining owing to the growing foreign presence. Among them, Western missionaries' evangelical undertakings including their hospitals, churches, schools, libraries and communities took the lead. Foreign missionaries and professionals may have favored Jining because of its relatively tolerant and stable urban condition, uncommon in the interior. As early as 1880, a German Catholic missionary working in Jining observed: "there is a much better opening for work in outside preaching here than at Tsi Nan (Jinan)." (Note 26)

From the changes of the religious situations in Jining, we can see certain general features in modern Chinese society. The advent of Western guns, goods, industry, modernity, capitalism and civilizations fundamentally reshaped the structure and trajectory of China. Eastern coasts, exemplified in the great trade ports such as Shanghai, Tianjin, Canton and Qingdao, took the lead in the modernization scheme of "learning from the West," while Jining, unlike most hinterlands that fell into backwardness or bankruptcy, also effectively followed this grand trend.

\section{References}

Dai, Y. T. (1980s). The beginning of the Christian church in Huangjia Street of Jining.

Esherick, J. W. (1987). The Origin of the Boxer Uprising. Berkeley, Los Angeles and London: University of California Press.

Anonymous. (1980s). Presbyterian Christianity in Jining.

Anonymous. (1980s). A brief survey of the church in the Paifang Street of Jining.

Anonymous. (1980s). Chart of former subsidiary Catholic institutions in the present Shizhong district of Jining.

Han, X. H. (1980s). The past and present of Daizhuang village.

Statistics on the religious and superstitious groups. dated on August 11, 1948. Jining Police office, Jining, Shizhong District Archives.

Jaspers, S. (1880). McIlvanie's letter of July 5, 1880. Shandong Provincial Archive, J 09-01-12.

Anonymous. (1927). Jining xianzhi. Gazetteer of Jining county.

Liu, H. B. (1980s). An Zhitai qiren.

Lu, Y. et al. (eds) (1980s). Jinan: Qi-Lu shushe.

Anonymous. (1995). A secret Japanese report from Mantetsu about Jining. Wenshi ziliao (Rencheng qu), 9(16).

Pomeranz, K. (1993). The Making of a Hinterland: State, Society, and Economy in Inland North China, 1853-1937. Berkeley: University of California Press.

Sheng, S. M. (1980s). Several "firsts" of Jining.

Sun, J. H. (2007). City, State, and the Grand Canal: Jining's Identity and Transformation, 1289-1937. Dissertation. The University of Toronto.

Sun, J. H. (2009). Resisting Marginalization in Late Qing China: Local Dynamics in Jining's Initial Modern Transformation, 1881-1911. East Asia: An International Quarterly, 26(3).

Sun, J. H. (2010). Building Urban Modernity in Hinterland China: Jining's Transition during the Early Republic (1912-1937). Journal of Asian History, 44, 1.

Sun, J. H. (2011). A Southern Identity in North China: the Making of Jining Urban Culture in the Late Imperial Period. Late Imperial China, 32(2). 
Xiao, H. S., \& Tang, C. T. (1988). Hui people and Islam in Jining. Wenshi ziliao (Shizhong qu), 4, 189-212.

Yuan, J. B. (1983). History of Jining's Jin Garden.

Zhang, Y. F. (1987). Modernization in China, 1800-1916: a regional study of social, political and economic change in Shantung province, monograph series no. 43(3). (Reprinted from Taipei: Institute of Modern History at the Academica Sinica, 1982.)

Zhao, C. D. (1980s). The recounts of the history of the Cathedral at Doujichang of Jining.

Zhao, C. D. (1988). A survey of the Catholic churches in Jining. Wenshi ziliao (Shizong qu), 4, 213-246.

Notes

Note 1. See case analyses in chapters 5-9 in Joseph Esherick, The Origins of the Boxer Uprising.

Note 2. In Western scholarship, the term "late imperial period" has been designated as a relatively distinct yet integral "longue durée" encompassing the Ming and Qing dynasties.

Note 3. See references in the second chapter "Canal-Oriented Economy and Urbanization" of my dissertation: Jinghao Sun, "City, State, and the Grand Canal: Jining's Identity and Transformation, 1289-1937." (Dissertation, the University of Toronto, 2007). In this chapter, I have examined how the Grand Canal route produced a commercially developed corridor on the North China Plain which subsequently induced urbanization. This specific path of urbanization implied that from the very beginning the fortunes of the new urban centers in this canal zone principally relied on the government-run canal transportation and trade.

Note 4. Joseph Esherick assumes that Jining was one of places in Shandong with the highest rate of ju-ren holders in the Qing. The Origins of the Boxer Uprising, 13.

Note 5. See references under the section titled "Gentry Society and Local Power Structure" in my dissertation "City, State, and the Grand Canal," 131-144.

Note 6. About Jining gentry's enterprise to remake the local cultural identity, see Jinghao Sun, "A Southern Identity in North China: the Making of Jining Urban Culture in the Late Imperial Period." Late Imperial China, Vo. 32, no. 2 (December 2011), 34-73.

Note 7. Xiao Hesheng and Tang Chengtao, "Jining de huizu he yisilan jiao," Wenshi ziliao (Shizhong qu), no. 4 (1988): 189-212.

Note 8. Joseph Esherick's scrutiny of the Boxer Rebellion indicates that backward western Shandong provided cultural soils for subversive thoughts. The Origins of the Boxer Uprising, 15-17.

Note 9. Kenneth Pomeranz, The Making of A Hinterland: State, Society, and Economy in Inland North China, 1853-1937, 155-159.

Note 10. See detailed data in Jinghao Sun, "Resisting Marginalization in Late Qing China: Local Dynamics in Jining's Initial Modern Transformation, 1881-1911." East Asia: An International Quarterly, Vol. 26, issue 3 (September 2009): 191-212.

Note 11. See references in Jinghao Sun, "Building Urban Modernity in Hinterland China: Jining's Transition during the Early Republic (1912-1937)." Journal of Asian History, 44-1 (August 2010): 1-36.

Note 12. Joseph Freinademetz and Johann Baptist von Anzer were once attacked and tortured by villagers in Caozhou in the 1880s. Lu Yao et al., eds., Shandong yihetuan diaocha ziliao xuanbian, 4.

Note 13. On November 1, 1897, two German Catholic priests Francis Xavier Nies and Richard Henle left their headquarters in Jining and were killed by swordsmen in Juye County. Lu Yao et al., eds., Shandong yihetuan diaocha ziliao xuanbian, 39-43. Joseph W. Esherick, The Origin of the Boxer Uprising, 123.

Note 14. Pope Leo XIII divided Shandong into northern, southern and eastern dioceses in 1885. References from Zhang Yufa, Zhongguo xiandaihua de quyu yanjiu: Shandong sheng, 161.

Note 15. Liu Huabing's manuscript on Johann Baptist von Anzer.

Note 16. Primary source were a few interviews collected in Lu Yao and others, eds., Shandong yihetuan diaocha ziliao xuanbian, 43-44. Other data from various manuscripts in the mid-1980s: Yuan Jingbo on the history of the Jin Garden - "Jining Jinyuan shihua"; Han Xuhe on history of Daizhuang village - "Daizhuang jinxi"; Zhao Chengdong on the history of Cathedral at Doujichang of Jining, "Jining Doujichang tianzhujiao zongtang jishi." In addition, see Zhao Chengdong's general survey "Mantan Jining de tianzhu jiaohui," Wenshi ziliao (Shizhong qu), no. 4 (1988): 213-246. 
Note 17. From an anonymous author's chart of former subsidiary Catholic institutions in the urban and suburban districts of Jining entitled "Jining shizhong qu tianzhu jiao yuan fushu jigou qingkuang biao."

Note 18. "Jining de jige diyi."

Note 19. An anonymous manuscript on Presbyterians in Jining: "Jidu jiao zhanglao hui zai Jining"; another anonymous manuscript on Paifang street: "Jining Paifang jie jiaohui jian jie."

Note 20. Dai Yutian's manuscript on the history of "Christian Church" in Huangjia street of Jining: "Jining Huangjia jie yesu jiaotang kaishi chuangban."

Note 21. Zhang Yufa, Zhongguo xiandaihua de quyu yanjiu: Shandong sheng, 162.

Note 22. Data from a Japanese Mantetsu secret report of Jining: "Rikou zai Jining xian de yifen mimi baogao," Wenshi ziliao (Rencheng qu), no. 9 (1995): 16.

Note 23. Statistics from Jining Police office, August 11, 1948, in the archive in Shizhong qu: "Huidao men mixin tuanti tongji biao."

Note 24. Jining xianzhi (1927), 2.75a.

Note 25. With the increasing advance of Japan in inland China, Japanese merchants quickly grew in Jining. Just before the Japanese incursion in 1938, there were about 300 Japanese who ran grocery stores, restaurants, hotels, workshops, and transportation companies, or acted as merchant agents. The Chinese version of the Mantetsu secret report "Rikou zai Jining xian de yifen mimi baogao," Wenshi ziliao (Rencheng qu), no. 9 (1995): 15-16.

Note 26. Jaspers S. McIlvanie's letter of July 5, 1880. Shandong Provincial Archive, J 109-01-12.

\section{Glossary}

Caozhou 曹州

Daizhuang 戴庄

Jin Yuan 荩园

Jining 济宁

ju-ren 举人

Juye 巨野

Qufu 曲阜

Yanzhou 充州

Yizhou 沂州

Zouxian 邹县 